\title{
Физика
}

\section{FORMATION OF COMPOUNDS BASED ON BISMUTH FERRITE WITH PARTIAL SUBSTITUTION OF BISMUTH IONS BY LANTHANUM AND PRASEODYMIUM}

\author{
Yu.A. Lupitskaya, D.A. Kalganov, Yu.O. Afanas'ev \\ Chelyabinsk State University, Chelyabinsk, Russian Federation \\ E-mail: lupitskaya@gmail.com
}

\begin{abstract}
Using the solid-phase reaction method we obtained bismuth ferrite based compounds generated by partial substitution of bismuth ions with rare earth metal ions (lanthanum and praseodymium). We used thermogravimetric analysis and X-ray analysis at the temperature range from 297 to $1123 \mathrm{~K}$ to study the peculiarities of the processes of phase formation of reaction-products synthesis in the systems which contain oxides of iron, bismuth, lanthanum, and praseodymium; their compositions were also determined. For the final synthesis temperature of $1123 \mathrm{~K}$ we determined a homogeneous concentration area, where bismuth ferrite solid solutions with the structure of distorted perovskite exist. We studied the influence of lanthanum and praseodymium oxides on phase composition of bismuth ferrite compounds in the process of isovalent alloying of a part of bismuth ions by lanthanum and praseodymium ions. In the frequency range of $20 \mathrm{~Hz}-1 \mathrm{MHz}$ we determined the key parameters, which characterize electrical and magnetic properties of perovskite-like phases. We found that for the considered samples the frequency dependencies of complex magnetic permeability and electrical parameters (real and alleged part of permittivity) are of almost the same type. We showed that for the given frequency range both electrical (complex permittivity) and magnetic (complex magnetic permeability) parameters decrease with the frequency increase.
\end{abstract}

Keywords: bismuth ferrite; solid solutions; distorted perovskite structure; electrical and magnetic properties.

\section{Introduction}

Multiferroic materials are inorganic compounds, which have both ferromagnetic and ferroelectric features. Such compounds can be used to create magnetoelectric materials, which can operate in various fields of microelectronics and microwave technology (e. g. extra-high density storage devices: magnetic memory, logical components, magnetic field sensors [1-3]). Therefore, the synthesis of new multiferroic materials attracts the great interest of researchers.

Bismuth ferrite $\left(\mathrm{BiFeO}_{3}\right)$ is a well-known multiferroic compound, in which dipole ordering occurs near $1100 \mathrm{~K}$ and antiferromagnetic ordering - near $640 \mathrm{~K}$. Hence, it can be used for the room temperature applications [4]. Besides, on the base of bismuth ferrite it is possible to create, using sol-gel processing and solid-state synthesis, solid solutions with the broad homogeneous region by double isovalent alloying of a part of $\mathrm{Bi}^{3+}$ ions by rare earth metal ions $\left(\mathrm{Ln}^{3+}\right)$, and of the same amount of $\mathrm{Fe}^{3+}$ by $\mathrm{Co}^{3+}$ ions. This modification can increase the possible number of application of such compounds [5]. However, the synthesis of monophase ceramic $\mathrm{BiFeO}_{3}$ in the system $\mathrm{Bi}_{2} \mathrm{O}_{3}-\mathrm{Fe}_{2} \mathrm{O}_{3}$ is hindered by the formation of transitional crystalline phases $\mathrm{Bi}_{2} \mathrm{Fe}_{4} \mathrm{O}_{9}$ and $\mathrm{Bi}_{25} \mathrm{FeO}_{39}$.

So, the intent of our work was to investigate the formation of bismuth ferrite solid solution in systems $\mathrm{Bi}_{2} \mathrm{O}_{3}-\mathrm{La}_{2} \mathrm{O}_{3}-\mathrm{Fe}_{2} \mathrm{O}_{3}$ and $\mathrm{Bi}_{2} \mathrm{O}_{3}-\mathrm{La}_{2} \mathrm{O}_{3}-\mathrm{Pr}_{6} \mathrm{O}_{11}-\mathrm{Fe}_{2} \mathrm{O}_{3}$ under heating in air. We considered the influence of lanthanum and praseodymium oxides on the phase composition of bismuth ferrite compounds in the process of isovalent alloying of a part of $\mathrm{Bi}^{3+}$ ions by $\mathrm{La}^{3+}$ and $\mathrm{Pr}^{3+}$ ions. We aimed to determine main parameters, which characterize magnetic and electrical properties of the obtained compounds. 


\section{Experiments}

We synthesized polycrystalline samples of solid solutions $\mathrm{Bi}_{1-x} \mathrm{La}_{x} \mathrm{FeO}_{3}(x=0 ; 0,05 ; 0,1 ; 1,0)$ and $\mathrm{Bi}_{0,9-x} \mathrm{La}_{0,1} \mathrm{Pr}_{x} \mathrm{FeO}_{3}(x=0 ; 0,05 ; 0,1 ; 0,7)$ by solid-phase reaction from chemically pure oxides $\mathrm{Bi}_{2} \mathrm{O}_{3}$, $\mathrm{Fe}_{2} \mathrm{O}_{3}, \mathrm{La}_{2} \mathrm{O}_{3}$, and $\mathrm{Pr}_{6} \mathrm{O}_{11}$. Oxides of rare earth metals $\left(\mathrm{La}_{2} \mathrm{O}_{3}\right.$ and $\left.\operatorname{Pr}_{6} \mathrm{O}_{11}\right)$ were thermally annealed at $1273 \mathrm{~K}$ for one hour. Mixtures, prepared according to preset quantities of starting reagents, were mixed and thoroughly ground in the agate mortar for 30 minutes with the addition of ethanol. The obtained alcohol-containing load was pressed under the pressure of $50 \mathrm{MPa}$ to cylinders with the diameter of $8 \mathrm{~mm}$ and thickness of 1-4 mm. The cylinders were thermally annealed at $1073 \mathrm{~K}$ in air for 3 hours. The synthesis of investigated compounds in air was made in the incinerator at $T_{1}=650 \mathrm{~K}$ ( 3 hours), $T_{2}=833 \mathrm{~K}$ ( 3 hours), $T_{3}=1093 \mathrm{~K}$ ( 3 hours) и $T_{4}=1123 \mathrm{~K}$ ( 6 hours) until the mass of the samples did not change.

We calculated the content of the obtained reaction products by weighting on the analytic balance of $0,05 \mathrm{mg}$ sensitivity.

Thermogravimetric measurements were done dynamically in air for broad temperature range (297$1123 \mathrm{~K}$ ), using the thermogravimetric analyzer "Derivatograph Q-1000" (Paulic-Erdey system) at the heating rate of 10 degrees in one minute.

After every isothermal exposition we examined the qualitative phase composition of the reaction products by the diffractometer DRON-3, using the standard procedure for polycrystalline powder: monochromatic $\mathrm{CuK \alpha _{1 }}$ radiation, diffraction angle $2 \theta$ from $13^{\circ}$ to $80^{\circ}$. The synthesized compounds were identified from the International Center for Diffraction Data database (JCPDS-ICDD).

Complex permittivity was calculated using the values of capacity frequency profile and loss angle (alternating current), which were measured in air at room temperature and the frequency range from $20 \mathrm{~Hz}$ to $1 \mathrm{MHz}$. Measurements were done using the meter RLC AKTAKOM AM-3028 (double contact method). Before that we coated the end faces of the cylinders with silver electrodes by baking of a silver conductive paste. We did not take into account errors which stem from the edge electric field and the field irregularities on the electrode surfaces because they are small.

To investigate a frequency profile of complex permeability we used the technique of a solenoid partial filling. We measured the inductance and the Q-factor of the coil with the sample inside. The instrument error was estimated taking into account the coil inductance (without the samples) and losses connected with the coil resistance and eddy currents in it.

\section{Results and discussion}

Solid solutions of $\mathrm{BiFeO}_{3}-\mathrm{LnFeO}_{3}$ are broadly investigated binary systems, where phases of $\mathrm{BiFeO}_{3}$ and $\mathrm{LnFeO}_{3}$ crystallize in the rhombohedral structure and the orthorhombic structure of perovskite type, respectively [5]. Isovalent alloying of a part of $\mathrm{Bi}^{3+}$ ions by $\mathrm{La}^{3+}$ and $\mathrm{Pr}^{3+}$ ions leads to the formation of solid solution $\mathrm{Bi}_{0,9-x} \mathrm{La}_{0,1} \mathrm{Pr}_{x} \mathrm{FeO}_{3}$, in which there is an orthorhombic distortion of perovskite unit cell. The unit cell parameters are determined for the $\mathrm{BiFeO}_{3}$ phase $\left(a=3,959 \AA\right.$ and $\left.\alpha=89^{\circ} 46^{\prime}\right)$.

From the analysis of X-ray patterns of $\mathrm{Bi}_{1-x} \mathrm{La}_{x} \mathrm{FeO}_{3}$ samples, synthesized by solid-phase reaction, the authors [5] noted that the quantitative content of mullite $\left(\mathrm{Bi}_{2} \mathrm{Fe}_{4} \mathrm{O}_{9}\right)$ and sillenite $\left(\mathrm{Bi}_{25} \mathrm{FeO}_{39}\right)$ phases increased with the increase of concentration $x$, starting from the molecular ratio $x>0.1$. This indicates the thermal instability of solid solutions based on bismuth ferrite. However, by X-ray diffraction analysis we showed that solid solutions $\mathrm{Bi}_{1-x} \mathrm{La}_{x} \mathrm{FeO}_{3}(x=0 ; 0,05 ; 0,1 ; 1,0)$ and $\mathrm{Bi}_{0,9-x} \mathrm{La}_{0,1} \operatorname{Pr}_{x} \mathrm{FeO}_{3}(x=0$; $0,05 ; 0,1 ; 0,7)$ had the crystal structure of perovskite with an orthorhombic distortion (see Fig. 1). Moreover, the percentage of impurity phases $\mathrm{Bi}_{2} \mathrm{Fe}_{4} \mathrm{O}_{9}$ and $\mathrm{Bi}_{25} \mathrm{FeO}_{39}$ did not exceed $3 \%$ at all investigated concentrations $x$.

Using thermogravimetric analysis we showed that the formation of bismuth ferrite and its derivatives was accompanied by a multistage decrease of samples masses in the broad temperature range (297 - $1123 \mathrm{~K}$ ), which indicates that physical and chemical processes in the considered systems were staged (see Fig. 2). The differential thermogram (DT) of the base mix $\left[\mathrm{Bi}_{2} \mathrm{O}_{3}-\mathrm{La}_{2} \mathrm{O}_{3}-\mathrm{Fe}_{2} \mathrm{O}_{3}\right] \cdot \mathrm{nH}_{2} \mathrm{O}$ had several peaks in low-temperature $(520-710 \mathrm{~K})$ and high-temperature regions $(780-1123 \mathrm{~K})$, which could be the evidence of change in the oxidation state of the metals in forming compounds (Fig. 2, $b$ ). 


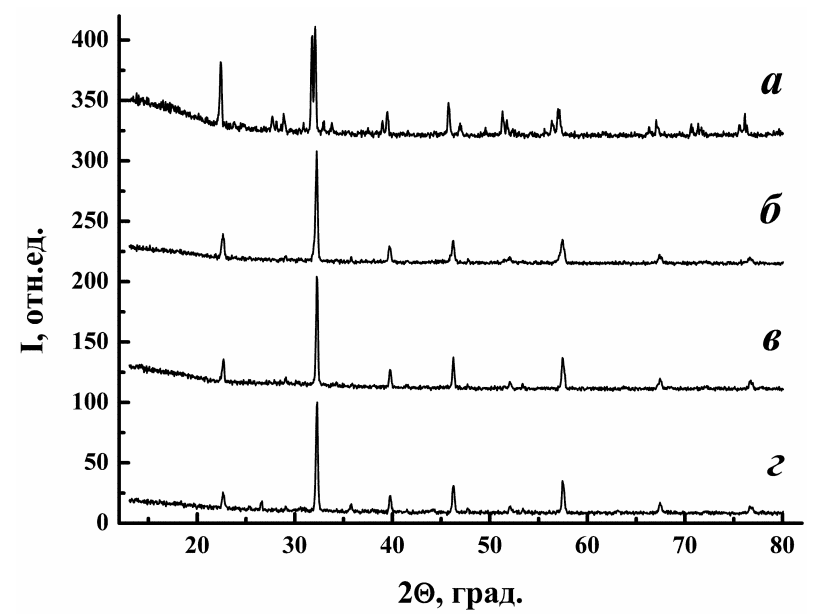

Fig. 1. X-ray patterns of samples, obtained using solid-phase reaction $(T=1123 \mathrm{~K}): a-\mathrm{BiFeO}_{3} ; b-\mathrm{Bi}_{0,8} \mathrm{La}_{0,2} \mathrm{FeO}_{3} ; c-$ $\mathrm{Bi}_{0,8} \mathrm{La}_{0,1} \mathrm{Pr}_{0,1} \mathrm{FeO}_{3} ; d-\mathrm{LaFeO}_{3}$. All samples have the crystal structure of perovskite with an orthorhombic distortion

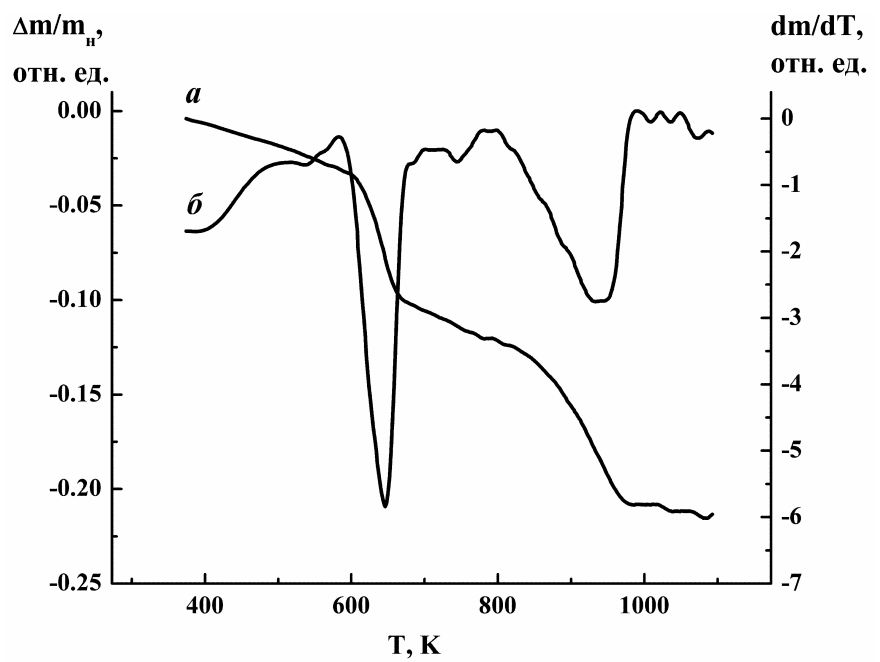

Fig. 2. Thermogram (a) and differential thermogram (b) of the base mix $\left[\mathrm{Bi}_{2} \mathrm{O}_{3}-\mathrm{La}_{2} \mathrm{O}_{3}-\mathrm{Fe}_{2} \mathrm{O}_{3}\right] \cdot \mathrm{nH}_{2} \mathrm{O}$

Low-temperature processing of compounds (at $650 \mathrm{~K}$ ) did not change the phase composition of samples. It can be seen from the XRD patterns with reflexes of the initial reagents of the corresponding oxide systems (see Fig. 3,a). The rise of temperature up to $833 \mathrm{~K}$ contributed toward the formation of crystalline phases in the synthesized powders, which can be seen from the appearance of fuzzy diffraction peaks (see Fig. 3, b). These peaks correspond to the reflexes of $\mathrm{BiFeO}_{3}$ phase. Further increase of fusion temperature (in the range 833-1093 K) resulted in the recrystallization process and formation of additional small peaks, which correspond to phases of $\mathrm{Bi}_{2} \mathrm{Fe}_{4} \mathrm{O}_{9}$ and $\mathrm{Bi}_{25} \mathrm{FeO}_{39}$ (Fig. 3, c).

So, by the experimental thermogravimetric and qualitative $\mathrm{X}$-ray diffraction analysis we showed that the formation of bismuth ferrite and its derivatives starts at temperature $\sim 833 \mathrm{~K}$, and at $T>833 \mathrm{~K}$ $\mathrm{BiFeO}_{3}$ decomposes with the formation of impurity phases. The number of these impurity phases did not rise with the increase of degree of substitution of lanthanum and praseodymium in the synthesized compounds.

Complex permittivity measurements showed that the real part of permittivity $\varepsilon^{\prime}$ (Fig. 4) and dielectric losses $\varepsilon^{\prime \prime}$ (Fig. 5) decreased with the frequency increase. The maximum value of permittivity $\left(\varepsilon^{\prime} \sim\right.$ $3750)$ and the minimum value of dielectric losses $\left(\varepsilon^{\prime \prime} \sim 1148\right)$ were obtained in the compound $\mathrm{Bi}_{0,7} \mathrm{La}_{0,1} \mathrm{Pr}_{0,2} \mathrm{FeO}_{3}$ at frequency $f=1 \mathrm{kHz}$.

Complex permeability of the considered samples had the similar type of the dependence on frequency as electric parameters (the real and the imaginary parts of permittivity). In the frequency range $20 \mathrm{~Hz}-1 \mathrm{MHz}$ the real part of permeability $\mu^{\prime}$ decreased with the frequency increase. The maximum value of $\mu^{\prime}(\sim 496)$ was obtained in the compound $\mathrm{Bi}_{0,9} \mathrm{La}_{0,1} \mathrm{FeO}_{3}$. 


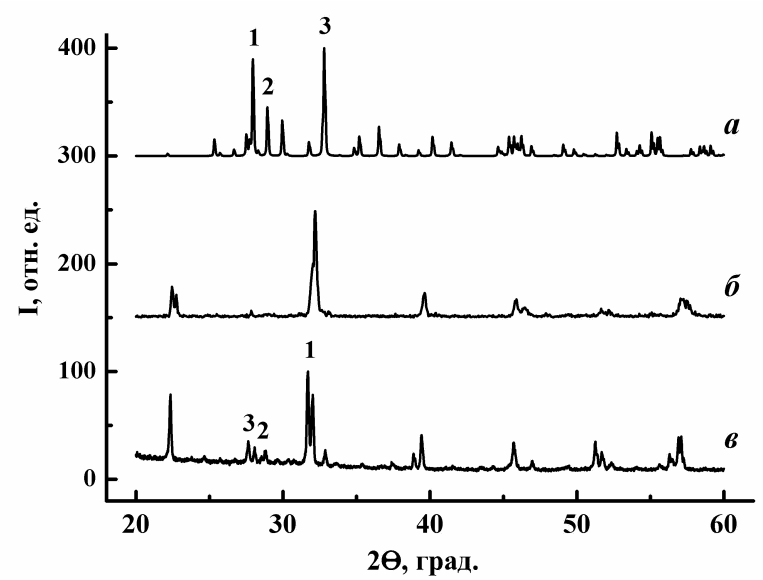

Fig. 3. X-ray patterns of samples, which form in systems $\mathrm{BiFeO}_{3}-\mathrm{LaFeO}_{3}$ and $\mathrm{Bi}(\mathrm{Pr}) \mathrm{FeO}{ }_{3}-\mathrm{LaFeO}_{3}$ at different fusion temperatures: $650 \mathrm{~K}\left(a ; 1-\mathrm{Bi}_{2} \mathrm{O}_{3} ; 2-\mathrm{La}_{2} \mathrm{O}_{3} ; 3-\mathrm{Fe}_{2} \mathrm{O}_{3}\right), 833 \mathrm{~K}\left(b ; \mathrm{BiFeO}_{3}\right), 1093 \mathrm{~K}\left(c ; 1-\mathrm{BiFeO}_{3} ; 2-\mathrm{Bi}_{2} \mathrm{Fe}_{4} \mathrm{O}_{9} ; 3-\right.$ $\left.\mathrm{Bi}_{25} \mathrm{FeO}_{39}\right)$

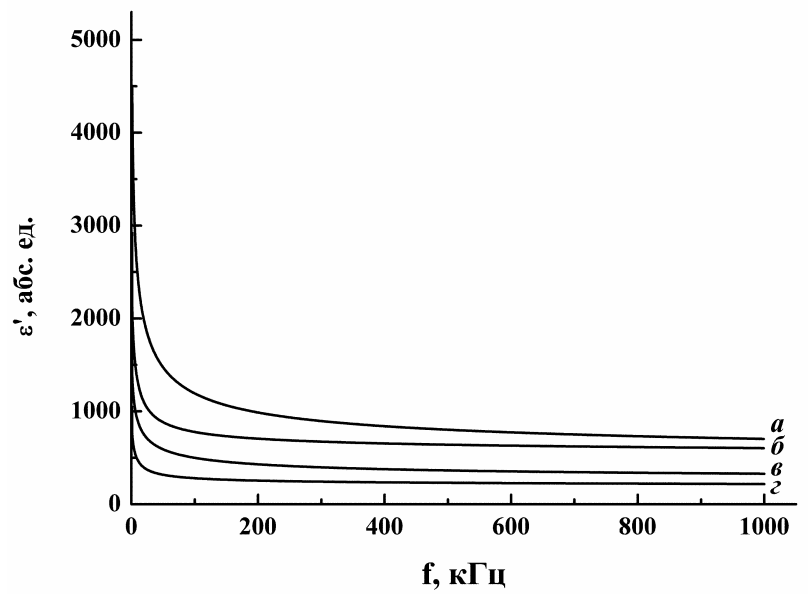

Fig. 4. Dependence of the real part of permittivity $\varepsilon^{\prime}$ on the frequency in the range $20 \mathrm{~Hz}-1 \mathrm{MHz}$ for compounds: $a-\mathrm{Bi}_{0,7} \mathrm{La}_{0,1} \mathrm{Pr}_{0,2} \mathrm{FeO}_{3} ; b-\mathrm{Bi}_{0,8} \mathrm{La}_{0,2} \mathrm{FeO}_{3} ; c-\mathrm{Bi}_{0,9} \mathrm{La}_{0,1} \mathrm{FeO}_{3} ; d-\mathrm{Bi}_{0,8} \mathrm{La}_{0,1} \mathrm{Pr}_{0,1} \mathrm{FeO}_{3}$

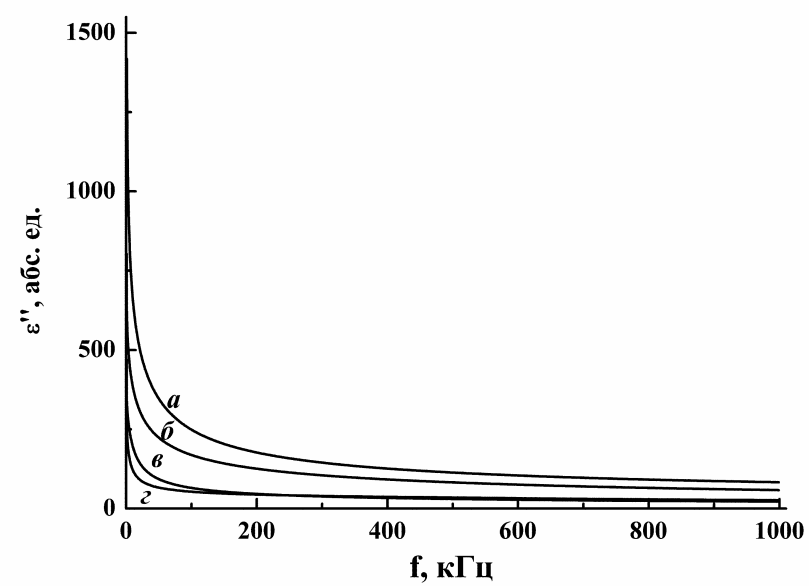

Fig. 5. Dependence of the imaginary part of permittivity $\varepsilon^{\prime}$ on the frequency in the range $20 \mathrm{~Hz}-1 \mathrm{MHz}$ for compounds: $a-\mathrm{Bi}_{0,7} \mathrm{La} \mathrm{a}_{0,1} \mathrm{Pr}_{0,2} \mathrm{FeO}_{3} ; \boldsymbol{b}-\mathrm{Bi}_{0,8} \mathrm{La}_{0,2} \mathrm{FeO}_{3} ; c-\mathrm{Bi}_{0,9} \mathrm{La}_{0,1} \mathrm{FeO}_{3} ; d-\mathrm{Bi}_{0,8} \mathrm{La}_{0,1} \mathrm{Pr}_{0,1} \mathrm{FeO}_{3}$ 


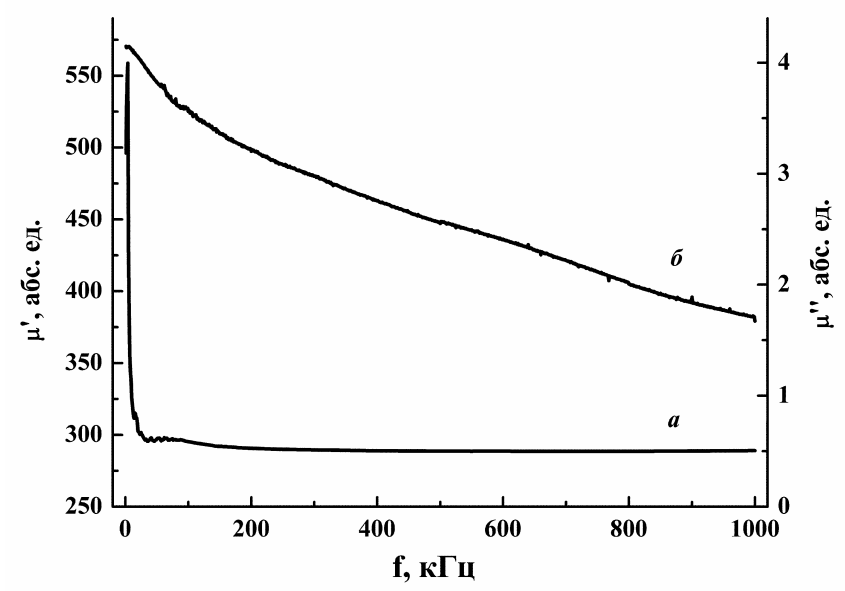

Fig. 6. Dependence of the real $\mu^{\prime}(a)$ and the imaginary $\mu^{\prime \prime}(b)$ parts of permeability on the frequency in the range $20 \mathrm{~Hz}-1 \mathrm{MHz}$ for the compound $\mathrm{Bi}_{0,9} \mathrm{La}_{0,1} \mathrm{FeO}_{3}$

\section{Conclusion}

We determined homogeneous concentration region, where solid solutions $\mathrm{Bi}_{1-x} \mathrm{La}_{x} \mathrm{FeO}_{3}$ and $\mathrm{Bi}_{0,9-\mathrm{x}} \mathrm{La}_{0,1} \mathrm{Pr}_{x} \mathrm{FeO}_{3}$ with the crystal structure of perovskite with an orthorhombic distortion exists. We found that the formation of bismuth ferrite and its derivatives starts at temperature $\sim 833 \mathrm{~K}$, and at $T>833 \mathrm{~K} \mathrm{BiFeO}_{3}$ decomposes with the formation of impurity phases of mullite $\left(\mathrm{Bi}_{2} \mathrm{Fe}_{4} \mathrm{O}_{9}\right)$ and sillenite $\left(\mathrm{Bi}_{25} \mathrm{FeO}_{39}\right)$. The number of these impurity phases does not rise with the increase of degree of substitution of lanthanum and praseodymium in the base compound $\mathrm{BiFeO}_{3}$. We showed that in perovskite-like phases in the frequency range $20 \mathrm{~Hz}-1 \mathrm{MHz}$ both electrical (complex permittivity) and magnetic (complex permeability) parameters decrease with the frequency increase. The maximum values of permittivity $\varepsilon^{\prime}$ and permeability $\mu^{\prime}$ were obtained in the compounds $\mathrm{Bi}_{0,7} \mathrm{La}_{0,1} \mathrm{Pr}_{0,2} \mathrm{FeO}_{3}$ and $\mathrm{Bi}_{0,9} \mathrm{La}_{0,1} \mathrm{FeO}_{3}$, respectively.

\section{Acknowledgments}

The reported study was funded by RFBR according to the research project No. 18-33-00269.

\section{References}

1. Zvezdin A.K., Pyatakov A.P. Phase transitions and the giant magnetoelectric effect in multiferroics. Phys. Usp. 2004, Vol. 47, no. 4, pp. 416-421. DOI: 10.1070/PU2004v047n04ABEH001752

2. Lupitskaya Y.A., Kalganov D.A., Abdrahmanova K.V. Phase formation in the $\mathrm{BaCO}_{3}-\mathrm{PbO}-$ $\mathrm{Fe}_{2} \mathrm{O}_{3}-\mathrm{Nb}_{2} \mathrm{O}_{5}$ system. The Journal of Surface Investigation. X-ray, Synchrotron and Neutron Techniques, 2017, Vol. 11, no. 1, pp. 87-91. DOI: 10.1134/S1027451016050347

3. Troyanchuk I.O., Bushinsky M.V., Chobot A.N., Mantytskaya O.S., Tereshko N.V. Weak ferromagnetism in $\mathrm{BiFeO}_{3}$-based multiferroics. Journal of Experimental and Theoretical Physics Letters, 2009, Vol. 89, no. 4, pp. 180-184. DOI: 10.1134/S0021364009040043

4. Troyanchuk I.O., Karpinsky D.V., Bushinsky M.V., Mantytskaya O.S., Tereshko N.V., Shut V.N. Phase Transition, Magnetic and Piezoelectric Properties of Rare-Earth-Substituted $\mathrm{BiFeO}_{3}$ Ceramics. Journal of the American Ceramic Society, 2011, Vol. 94, no. 12, pp. 4502-4506. DOI: $10.1111 /$ j.1551-2916.2011.04780.x

5. Zatyupo A.A., Bashkirov L.A., Petrov G.S., Shichkova T.A. Fiziko-himicheskie svojstva tverdyh rastvorov $\mathrm{Bi}_{1-x} \mathrm{La}_{x} \mathrm{Fe}_{1-x} \mathrm{Co}_{x} \mathrm{O}_{3}$, sintezirovannyh s ispol'zovaniem raznyh metodov (Physical and chemical properties of solid solution $\mathrm{Bi}_{1-x} \mathrm{La}_{x} \mathrm{Fe}_{1-x} \mathrm{Co}_{x} \mathrm{O}_{3}$ synthesized by different methods. Trudy BGTU. No. 3 . Himiya i tekhnologiya neorganicheskih materialov $i$ veshchestv, 2012, no. 3, pp. 37-41. (in Russ.).

Received January 30, 2018 


\title{
ОБРАЗОВАНИЕ СОЕДИНЕНИЙ НА ОСНОВЕ ФЕРРИТА ВИСМУТА ПРИ ЧАСТИЧНОМ ЗАМЕЩЕНИИ ИОНОВ ВИСМУТА ИОНАМИ ЛАНТАНА И ПРАЗЕОДИМА ${ }^{1}$
}

\author{
Ю.А. Лупицкая, Д.А. Калганов, Ю.О. Афанасьев \\ Челябинский государственный университет, г. Челябинск, Российская Федерация \\ E-mail: lupitskaya@gmail.com
}

Методом твердофазной реакции получены соединения на основе феррита висмута, образующиеся при частичном замещении ионов висмута ионами редкоземельных металлов - лантана и празеодима. В интервале температур от 297 до 1123 К методами термогравиметрического и рентгеновского анализа исследованы особенности процессов фазообразования синтеза продуктов реакций в системах, содержащих оксиды железа, висмута, лантана и празеодима, определены их составы. Для конечной температуры синтеза 1123 К выявлена гомогенная концентрационная область существования твердых растворов феррита висмута, имеющих структуру искаженного перовскита. Изучено влияние оксидов лантана и празеодима на фазовый состав соединений феррита висмута при изовалентном легировании части ионов висмута ионами лантана и празеодима. В частотном диапазоне (20 Гц - 1 МГц) установлены основные параметры, характеризующие электрические и магнитные свойства перовскитоподобных фаз. Установлено, что характер частотной зависимости комплексной магнитной проницаемости исследуемых образцов существенно не отличается от частотной зависимости электрических параметров (вещественной и мнимой части диэлектрической проницаемости). Показано, что во всем заданном диапазоне наблюдается уменьшение как электрических (комплексной диэлектрической проницаемости), так и магнитных параметров (комплексной магнитной проницаемости) с ростом частоты.

Ключевые слова: феррит висмута; твердые растворы; структура искаженного перовскита; электрические и магнитные свойства.

\section{Литература}

1. Звездин, А.К. Фазовые переходы и гигантский магнитоэлектрический эффект в мультиферроиках / А.К. Звездин, А.П. Пятаков // УФН. - 2004. - Т. 174, № 4. - C. 465-470. DOI: 10.3367/UFNr.0174.200404n.0465

2. Лупицкая, Ю.А. Фазообразование в системе $\mathrm{BaCO}_{3}-\mathrm{PbO}-\mathrm{Fe}_{2} \mathrm{O}_{3}-\mathrm{Nb}_{2} \mathrm{O}_{5}$ / Ю.А. Лупицкая, Д.А. Калганов, К.В. Абдрахманова // Поверхность. Рентгеновские, синхротронные и нейтронные исследования. - 2016.- № 12. - С. 84-88.

3. Слабый ферромагнетизм в мультиферроиках на основе $\mathrm{BiFeO}_{3} /$ И.О. Троянчук, М.В. Бушинский, А.Н. Чобот и др. // Письма в ЖЭТФ. - 2009. - Т. 89. - Вып. 4. - С. 204-208.

4. Phase Transition, Magnetic and Piezoelectric Properties of Rare-Earth-Substituted $\mathrm{BiFeO}_{3} \mathrm{Ce}-$ ramics / I.O. Troyanchuk, D.V. Karpinsky, M.V. Bushinsky // Journal of the American Ceramic Society. - 2011. - Vol. 94. - Issue 12. - P. 4502-4506.

5. Физико-химические свойства твердых растворов $\mathrm{Bi}_{1-x} \mathrm{La}_{x} \mathrm{Fe}_{1-x} \mathrm{Co}_{x} \mathrm{O}_{3}$, синтезированных с использованием разных методов / А.А. Затюпо, Л.А. Башкиров, Г.С. Петров, Т.А. Шичкова // Труды БГТУ. № 3. Химия и технология неорганических материалов и веществ. -2012 . - № 3. C. $37-41$.

Поступила в редакцию 30 января 2018 г.

\footnotetext{
${ }^{1}$ Исследование выполнено при финансовой поддержке РФФИ в рамках научного проекта № 18-33-00269 